\title{
PENGARUH DERAJAT DEASETILASI KITOSAN DENGAN PERLAKUAN ALKALI BERBEDA TERHADAP KUALITAS EDIBLE FILM
}

\author{
Dwi Setijawati $^{\mathrm{a}, \mathrm{b} *}$, Yahya $^{\mathrm{a}, \mathrm{b} *}$, Dinda $\operatorname{Ersyah}^{\mathrm{b}}$ \\ a) Bioseafood Research Grup, Fakultas Perikanan Dan Ilmu Kelautan, Universitas Brawijaya \\ b) Program Studi Teknologi Hasil Perikanan, Fakultas Perikanan Dan Ilmu Kelautan, Universitas \\ Brawijaya
}

*Koresponden penulis : dwisetyawati@ub.ac.id

\begin{abstract}
Abstrak
Penelitian ini bertujuan untuk menentukan jenis dan konsentrasi alkali untuk menghasilkan kitosan dengan nilai derajat deasetilasi tertinggi dan untuk mengetahui pengaruh nilai derajat deasetilasi kitosan terhadap kualitas edible coating yang dihasilkan. Bahan dasar edible coating yang dibuat adalah kappa karagenan, iota karagenan dan kitosan. Kitosan yang diberi perlakuan variasi jenis alkali ( $\mathrm{KOH}$ dan $\mathrm{NaOH})$ dan variasi konsentrasi $(55 \%, 60 \%, 65 \%)$ ditentukan derajat deasetilasi. Edible film dibuat berdasarkan kitosan yang diketahui derajat deasetilasinya kemudian diuji kualitas. Jenis dan konsentrasi alkali berpengaruh signifikan terhadap nilai derajat deasetilasi kitosan. Nilai derajat deasetilasi kitosan tertinggi didapatkan dengan perlakuan $\mathrm{NaOH} 65 \%$ sebesar 84,36\%. Nilai deasetilasi kitosan berpengaruh signifikan terhadap kualitas edible film. Kadar air, elongasi, kuat tarik, ketebalan dan transmisi uap air edible film secara berurutan yaitu berkisar 10,83\% - 17,67\%; 6,95\% - 8,58\%; 41,07 N/cm $\mathrm{cm}^{2}-72,76 \mathrm{~N} / \mathrm{cm}^{2} ; 39,86 \mu \mathrm{m}-58,67$ $\mu \mathrm{m} ;, 0,26 \mathrm{~g} / \mathrm{m}^{2} \mathrm{jam}-0,26 \mathrm{~g} / \mathrm{m}^{2} \mathrm{jam}$.
\end{abstract}

Kata kunci: derajat deasetilasi, edible film, kitosan

\begin{abstract}
The aim of this study was to determine the type and concentration of alkali to produce chitosan with the highest degree of deacetylation value and to determine the effect of the degree of deacetylation value of chitosan on the quality of the edible coating. The basic ingredients for the edible coating were kappa carrageenan, iota carrageenan and chitosan. Chitosan was treated with various types of alkali $(\mathrm{KOH}$ and $\mathrm{NaOH})$ and various concentrations $(55 \%, 60 \%, 65 \%)$ and the degree of deacetylation was determined. Edible film was made based on chitosan with degree of deacetylation known and then tested for the quality. The type and concentration of alkali had a significant effect on the value of the degree of deacetylation of the chitosan. The highest value of chitosan degree of deacetylation was obtained by $65 \% \mathrm{NaOH}$ treatment of $84.36 \%$. The degree of deacetylation of chitosan has a significant effect on the quality of the edible film. Water content, elongation, tensile strength, thickness and water vapor transmission of the edible film, respectively, ranged from $10.83 \%$ - 17.67\%; 6.95\% - 8.58\%; $41.07 \mathrm{~N} / \mathrm{cm}^{2}-72.76 \mathrm{~N} / \mathrm{cm}^{2} ; 39.86 \mu \mathrm{m}-58.67 \mu \mathrm{m} ; 0,05 \mathrm{~g} / \mathrm{m}^{2}$ hours $-0,26 \mathrm{~g} / \mathrm{m}^{2}$ hours.
\end{abstract}

Keywords: chitosan, degree of deacetylation, edible film

\section{PENDAHULUAN}

Edible film adalah segala jenis bahan yang digunakan untuk membungkus bahan lain untuk melindungi produk yang dapat dikonsumsi bersamaan dengan atau tanpa dihilangkan. Edible film dapat digunakan sebagai lapisan pengganti atau fortifikan alami untuk mencegah kehilangan air dan komponen penting lainnya. Bahan utama yang umumnya digunakan dalam pembuatan edible film antara lain hidrokoloid (polisakarida dan protein), dan lemak atau komposit. Bahan yang digunakan mempengaruhi kualitas edible film seperti kuat tarik, elongasi, ketebalan dan transmisi uap air [1]. Polisakarida yang bisa digunakan sebagai bahan pembuatan edible film adalah 
karagenan dan kitosan. Karagenan dan kitosan dapat membentuk sifat biokompatibel.

Karagenan dikenal sebagai salah satu jenis hidrokoloid yang membentuk dispersi kental atau gel ketika didispersikan dalam air. Karagenan adalah polisakarida sulfat yang larut dalam air yang diekstrak dari rumput laut merah (Rhodophyta). Secara umum, karagenan terdiri dari ester sulfat dari galaktosa dan polisakarida 3,6 hidrohidrogalaktosa, dan residu D-galaktosa yang dihubungkan secara bergantian dalam ikatan $\alpha-1,3$ dan $\beta-1,4$ [2]. Karagenan diklasifikasikan berdasarkan polisakarida alami menjadi kappa (k-), iota (i-) dan lambda $(\lambda)$. Kappa dan iota karagenan memiliki kemampuan untuk membentuk gel termoreversibel dan termasuk anionik polisakarida yang membantu pembentukan gel [3]. Kappa dan iota karagenan diketahui banyak digunakan dalam industri makanan untuk meningkatkan tekstur dan struktur mikro gel [4]. Kappa berfungsi untuk penebalan, mengikat air, dan pembentuk gel. Iota menunjukkan sifat viskoelastik untuk membentuk gel [5].

Kitosan adalah polisakarida yang didapat secara alami pada dinding sel beberapa krustasea, tanaman dan fungi dan termasuk kelompok polisakarida yang bersifat kationik. Kitosan $(\beta-(1,4)$-linked D-glucosamine) merupakan turunan utama kitin. Pemanfaatan kitosan sebagai biopolimer alam yang melimpah dan tidak beracun dapat dimanfaatkan di bidang industri modern seperti pengkelat logam, pengawet, antioksidan, absorban warna, serta pemisahan protein [6]. Kitosan $\left(\mathrm{C}_{6} \mathrm{H}_{11} \mathrm{NO}_{4}\right)_{\mathrm{n}}$ berbentuk padatan amorf berwarna putih kekuningan, bersifat polielektrolit. Umumnya larut dalam asam organik, $\mathrm{pH}$ sekitar 4-6,5; tidak larut pada $\mathrm{pH}$ yang lebih rendah atau lebih tinggi. Kitosan dihasilkan melalui deasetilasi kitin menggunakan pelarut alkali dengan konsentrasi tinggi dan suhu tinggi. Fungsi alkali adalah memutus ikatan antar karbon pada gugus asetil $\left(-\mathrm{CH}_{3} \mathrm{COO}\right)$ dengan nitrogen yang ada pada kitin. Gugus asetil akan terlepas kemudian gugus amina $\left(-\mathrm{NH}_{2}\right)$ terbentuk. Presentase gugus asetil yang terlepas selama proses deasetilasi disebut sebagai nilai derajat deasetilasi [7].
Penelitian mengenai pembuatan edible film telah banyak dilakukan sebelumnya [8][9][10]. Multikomponen edible film yang terdiri dari campuran dapat dikembangkan umtuk memiliki sifat fungsional yang dapat mempengaruhi kualitasnya [9]. Biokompatibilitas campuran antara karagenan dan kitosan karena adanya sifat anionik dan kationik. Disamping interaksi sifat anionik dan kationik karagenan dan kitosan, maka derajad deasetilasi (DD) kitosan dapat mempengaruhi sifat fisik edible film yang dihasilkan. Penelitian yang sebelumnya belum ditemukan tentang tentang hubungan derajat deasetilasi kitosan yang digunakan sebagai bahan pembuat kitosan dan interaksinya dengan karagenan sebagai bahan pembuatan edible film menjadi latar belakang penelitian ini untuk dilakukan. Penelitian ini bertujuan untuk menentukan jenis dan konsentrasi basa untuk menghasilkan kitosan dengan nilai derajat deasetilasi tertinggi dan untuk mengetahui pengaruh nilai derajat deasetilasi kitosan terhadap kualitas edible coating yang dihasilkan.

\section{METODE}

\section{Bahan}

Bahan utama yang digunakan dalam penelitian ini antara lain Eucheuma cottonii kering untuk membuat kappa karagenan, Eucheuma spinosum kering untuk membuat iota karagenan, dan limbah cangkang udang untuk membuat kitosan. Bahan kimia untuk pembuatan produk menggunakan standar teknis dan pengujian Analisa menggunakan standar pro analis (pa).

\section{Pembuatan Kappa dan Iota Karagenan [9]}

E. cottonii kering ditimbang dan dibersihkan. Kemudian direbus dalam larutan $\mathrm{KOH}$ dengan konsentrasi $6 \%(\mathrm{w} / \mathrm{v})$ pada suhu $70-74^{\circ} \mathrm{C}$ selama 2 jam. Lalu dicuci dengan hingga bau $\mathrm{KOH}$ hilang. Setelah itu rumput laut hasil ekstraksi dipotong dengan ukuran 2$3 \mathrm{~cm}$, dilanjutkan dengan langkah pengeringan. Lalu dilakukan penggilingan untuk menjadi Semi Refine Caragenan (SRC) bubuk. 
Langkah yang sama dilakukan pada proses pembuatan iota karagenan dengan perbedaan yaitu menggunakan E. spinosum dan larutan yang digunakan adalah $\mathrm{Ca}(\mathrm{OH})_{2}$.

\section{Pembuatan Kitosan [9]}

Pembuatan kitosan dilakukan dengan mengisolasi kitin dari cangkang udang lalu dilanjutkan dengan proses deasetilasi. Tahap isolasi kitin melalui tahap deproteinasi dan demineralisasi. Tahap demineralisasi dilakukan dengan cara cangkang udang kering ditambahkan dengan $\mathrm{NaOH} 3,5 \%$ dengan perbandingan 1:10 (w/v). Campuran larutan ini direndam dan diaduk menggunakan magnetic stirrer selama \pm 2 jam pada suhu $65^{\circ} \mathrm{C}$. Langkah selanjutnya adalah pencucian dengan akuades lalu dikeringkan dalam oven suhu $80^{\circ} \mathrm{C}$. Selanjutnya dilakukan tahap demineralisasi, hasil deproteinasi ditambahkan larutan $\mathrm{HCl} 1 \mathrm{~N}$ dengan perbandingan 1:20 (w/v). Kemudian direndam dan diaduk menggunakan magnetic stirrer selama 30 menit pada suhu $65^{\circ} \mathrm{C}$. Langkah selanjutnya adalah pencucian dengan akuades lalu dikeringkan dalam oven suhu $80^{\circ} \mathrm{C}$.

Proses selanjutnya adalah proses transformasi kitin menjadi kitosan. Kitin diberi perlakuan basa yang berbeda, yaitu $\mathrm{KOH}$ $(55 \%, 60 \%, 65 \%)$ dan $\mathrm{NaOH}(55 \%, 60 \%$, $65 \%$ ) dengan perbandingan kitin dan larutan basa 1:20 (w/v). Campuran tersebut dipanaskan dengan suhu $120^{\circ} \mathrm{C}$ selama 2 jam. Kemudian disaring dan dicuci dengan akuades sampai $\mathrm{pH}$ netral. Selanjutnya dikeringkan menggunakan oven pada suhu $80^{\circ} \mathrm{C}$ sampai kering. Mekanisme deasetilasi kitin menurut Minda et al. (2010) yaitu gugus karbon karbonil diserang oleh $\mathrm{OH}^{-}$sehingga terjadi reaksi adisi. Reaksi adisi membentik zat antara yang selanjutnya mengalami reaksi eliminasi. Reaksi eliminasi melepas asetamida kitin dan membentuk asetat.

\section{Uji Derajat Deasetilasi}

Kitosan dikarakterisasi menggunakan spektrofotometer FT-IR pada daerah gugus fungsi dan daerah sidik jari dengan frekuensi $4000-400 \mathrm{~cm}^{-1}$. Perhitungan derajat deasetilasi
(DD) dari spektra infra merah pada kitosan dilakukan dengan membandingkan absorbansi pada bilangan gelombang untuk gugus amidaNH (A1655) dengan absorbansi pada bilangan gelombang untuk gugus amina primer (A3450), dengan nilai absorbansi 1,33 pada proses deasetilasi sempurna [11]. Persamaan yang dipakai yaitu:

$$
\begin{gathered}
\mathrm{DD}=100-\left[\left(\frac{\mathrm{A} 1655}{\mathrm{~A} 3450}\right) \times \frac{100}{1,33}\right] \\
\mathrm{A}=\log \frac{\mathrm{To}}{\mathrm{T}}
\end{gathered}
$$

Dimana,

To $=\% \mathrm{~T}$ pada garis dasar

$\mathrm{T}=\% \mathrm{~T}$ pada puncak

\section{Pembuatan Edible Film}

Pembuatan edible film dalam penelitian ini menggunakan metode Setijawati [9]. Pembuatan bahan edible film dalam penelitian ini terdiri dari campuran kappa karagenan, iota caragenan dan kitosan (0,5:0,5:1). Kappa karagenan, iota caragenan dan kitosan ditambahkan dalam $80 \mathrm{ml}$ aquades. Larutan dipanaskan menggunakan hot plate pada suhu $60^{\circ} \mathrm{C}$, ditambahkan $1 \mathrm{ml}$ gliserol sebagai plasticizer dan aquades sehingga volumenya $100 \mathrm{ml}$. Suhu dinaikkan menjadi $80^{\circ} \mathrm{C}$. Larutan kemudian dituang dalam nampan plastik lalu dikeringan menggunakan oven pada suhu $50^{\circ} \mathrm{C}$ selama 24 jam.

\section{Uji Kadar Air}

Pengujian kadar air menggunakan metode gravimetri berdasarkan AOAC 2005 [12]. Perhitungan kadar air dihitung dengan persamaan berikut:

Kadar air $(\% \mathrm{bb})=\frac{\text { berat awal-berat akhir }}{\text { berat sampel }} \times 100 \%$

\section{Uji Elongasi}

Elongasi dihitung dengan membandingkan panjang edible film saat putus dan panjang edible film sebelum ditarik oleh alat [13]. 


\section{Uji Kuat Tarik}

Analisis kuat tarik dilakukan dengan menggunakan Texture Profile Analyzer Imada Force Measurement tipe ZP-200N. Alat menunjukkan besar gaya yang diperlukan untuk memutuskan edible film. Berikut ini adalah rumus untuk menghitung kuat tarik:

$$
\text { Kuat Tarik }\left(\mathrm{N} / \mathrm{cm}^{2}\right)=\frac{\text { Gaya }(\mathrm{N})}{\operatorname{Luas}\left(\mathrm{cm}^{2}\right)}
$$

\section{Uji Ketebalan}

Pengukuran ketebalan edible film menggunakan hand micrometer dengan ketelitian $0,01 \mathrm{~mm}$ pada 3 titik berbeda, kemudian hasil pengukuran dirata-rata [14]. Ketebalan film dinyatakan dalam satuan $\mathrm{mm}$ dan micrometer yang digunakan mempunyai ketelitian $\mu \mathrm{m}$. Ketebalan dapat dihitung dengan rumus:

Tebal $=\frac{\text { Tebal atas }+ \text { Tebal tengah }+ \text { Tebal bawah }}{3}$

\section{Uji Transmisi Uap Air}

Edible film yang akan diuji dipotong. Kemudian wadah diisi $15 \mathrm{~mL}$ aquadest dan ditempatkan di wadah 2 yang berisi silica gel. Sebelum itu, silica gel dikeringkan pada suhu $180^{\circ} \mathrm{C}$ selama 3 jam. Lalu wadah 2 disimpan pada suhu $25^{\circ} \mathrm{C}$. Pengukuran dilakukan setelah penyimpanan pada jam ke 24. Tranmisi uap air dihitung dengan rumus:

$$
\mathrm{TUA}=\frac{\Delta \mathrm{W}}{\mathrm{t} \times \mathrm{A}}
$$

Keterangan:

$\Delta \mathrm{W}=$ Perubahan setelah $24 \mathrm{jam}$

$\mathrm{t} \quad=$ Waktu (24 jam)

A $=$ Luas permukaan film $\left(\mathrm{m}^{2}\right)$

\section{HASIL DAN PEMBAHASAN}

\section{Derajat Deasetilasi Kitosan}

Kitosan yang dihasilkan dari deasetilasi kitin dikarakterisasi menggunakan spektroskopi infra merah (FTIR). Spektrum FTIR kitosan yang dihasilkan dari penelitian dapat dilihat pada Gambar 1 dan Gambar 2. Perhitungan derajat deasetilasi dapat dilakuakn dari hasil spektra infra merah kitosan dengan cara membandingkan absorbansi pada bilangan gelombang untuk gugus amida NHCO $\left(1650 \mathrm{~cm}^{-1}-1500 \mathrm{~cm}^{-1}\right)$ dengan absorbansi pada bilangan gelombang untuk gugus amina primer $-\mathrm{NH}_{2}\left(3500 \mathrm{~cm}^{-1}-3200\right.$ $\mathrm{cm}^{-1}$ ). 


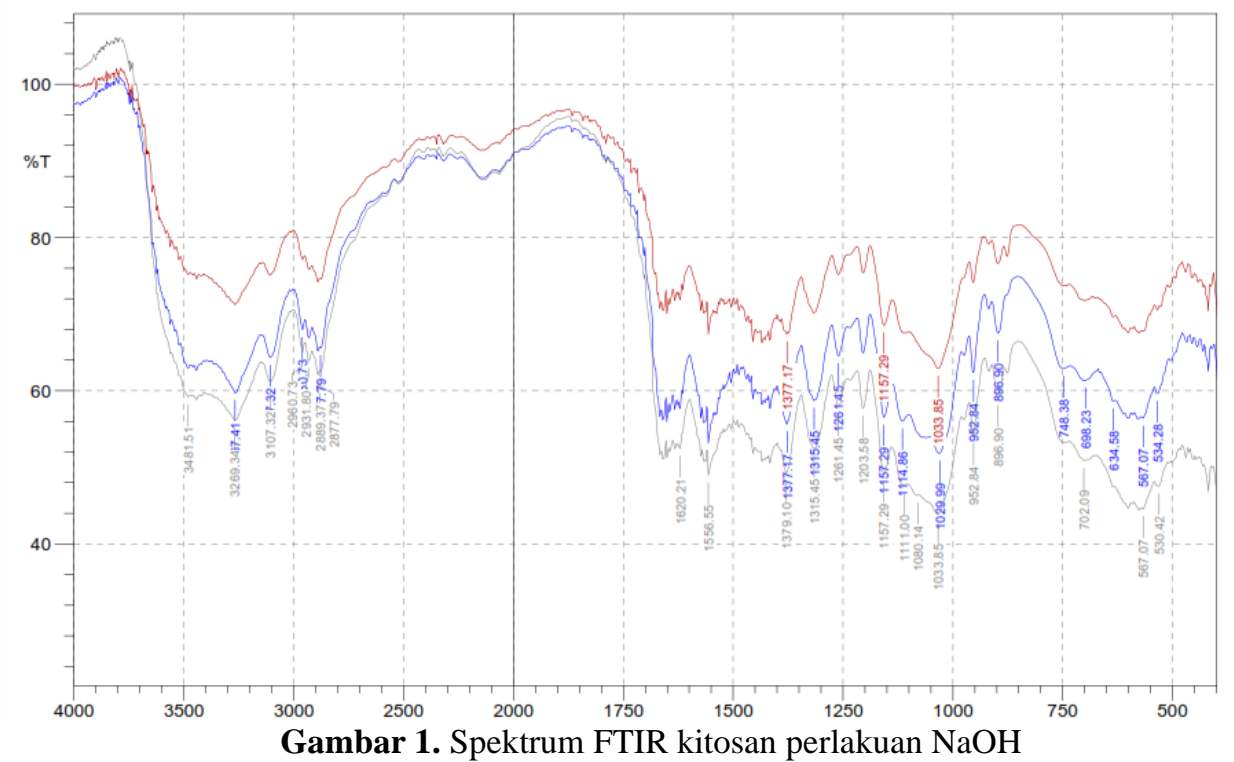

$($ Merah $=55 \%$; Biru $=60 \%$; Putih 65\%)

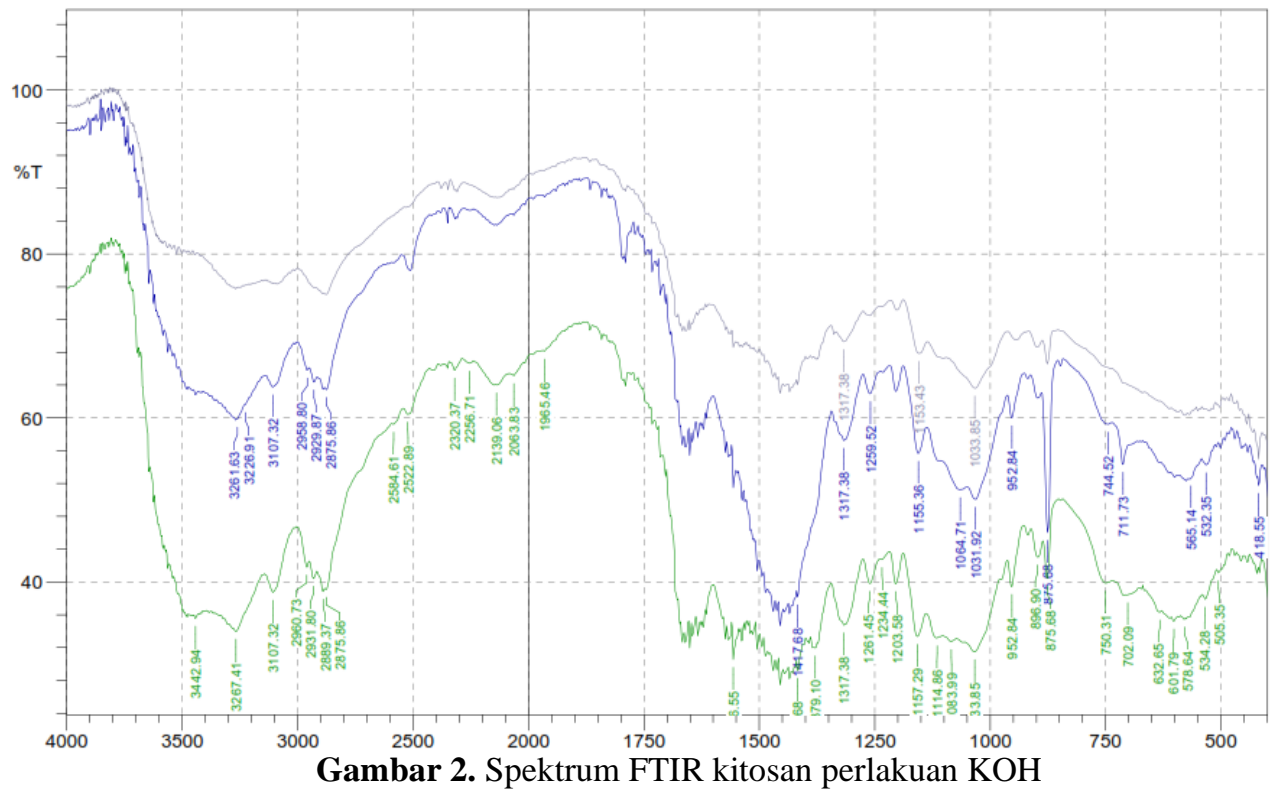

$($ Putih $=55 \% ;$ Biru $=60 \% ;$ Hijau 65\%)

Derajat deasetilasi (DD) merupakan nilai hilangnya gugus asetil pada gugus asetamida kitin atau banyakya gugus amino bebas yang dihasilkan setelah proses deasetilasi. Semakin tinggi nilai DD maka semakin banyak gugus amin $\left(-\mathrm{NH}_{2}\right)$ pada molekul kitosan, sehingga kitosan semakin reaktif. Nilai DD kitosan yang dihasilkan dari 
penelitian perlakuan jenis basa $(\mathrm{NaOH}$ dan $\mathrm{KOH})$ dan konsentrasi $(55 \%, 60 \%, 65 \%)$ dapat dilihat pada Tabel 1. Nilai DD kitosan yang dihasilkan 57,25\% hingga 84,36\%.

\begin{tabular}{cr}
\hline Perlakuan & $\begin{array}{r}\text { Rata-rata derajat } \\
\text { deasetilasi (\%) }\end{array}$ \\
\hline NaOH 55\% & $71,51 \pm 0,104^{\mathrm{c}}$ \\
NaOH 60\% & $79,54 \pm 0,003^{\mathrm{e}}$ \\
NaOH 65\% & $84,36 \pm 0,154^{\mathrm{f}}$ \\
KOH 55\% & $57,25 \pm 0,013^{\mathrm{a}}$ \\
$\mathrm{KOH} 60 \%$ & $61,33 \pm 0,019^{\mathrm{b}}$ \\
KOH 65\% & $74,57 \pm 0,007^{\mathrm{d}}$ \\
\hline
\end{tabular}

Tabel 1. Nilai derajat deasetilasi kitosan

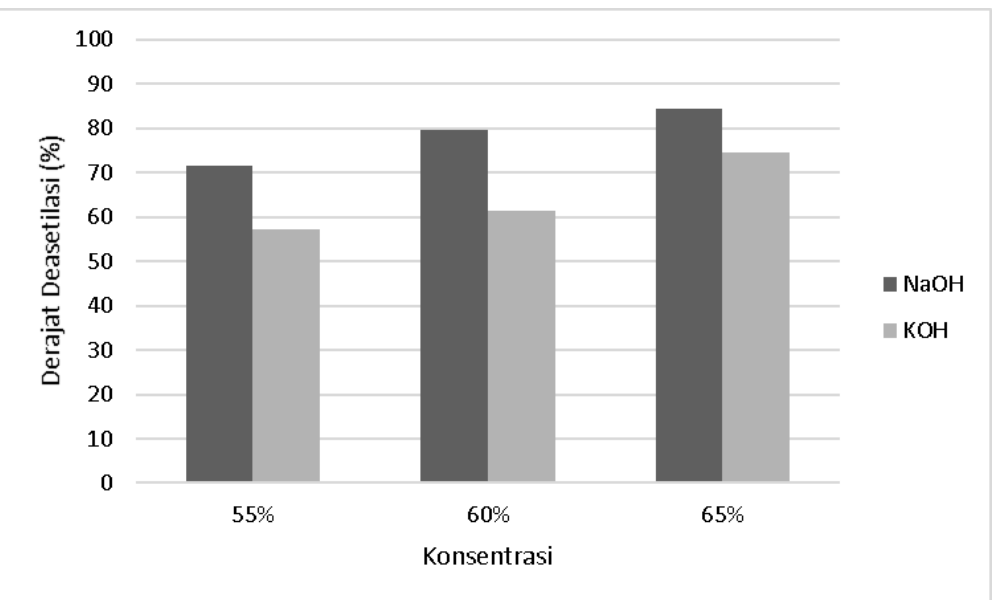

Gambar 3. Grafik perbandingan pengaruh perlakuan

konsentrasi $\mathrm{NaOH}$ dan $\mathrm{KOH}$ terhadap derajat deasetilasi

Pengaruh penggunaan konsentrasi $\mathrm{NaOH}$ dan $\mathrm{KOH}$ terhadap DD digambarkan pada grafik (Gambar 3). Grafik menunjukkan nilai DD kitosan perlakuan $\mathrm{NaOH}$ cenderung lebih tinggi daripada perlakuan $\mathrm{KOH}$. Konsentrasi ion $\mathrm{OH}^{-}$pada basa kuat berhubungan dengan proses pelepasan gugus asetil dari gugus asetamida kitin sehingga mempengaruhi nilai DD kitosan $(\mathrm{p}<0,05)$. Semakin tinggi konsentrasi yang digunakan, semakin besar nilai DD kitosan. Nilai DD tertinggi adalah perlakuan $\mathrm{NaOH} 65 \%$ dan terendah adalah perlakuan $\mathrm{KOH} 55 \%$. Berdasarkan tabel sistem periodik, unsur $\mathrm{Na}$ memiliki afinitas elektron yang lebih negatif dan keelektronegatifan yang lebih tinggi dari pada unsur K. Sehingga, Na lebih cenderung untuk menarik pasangan elektron dalam molekulnya. Semakin tinggi keelektronegatifan, semakin meningkatkan reaksi eliminasi [15]. Elektronegativitas adalah ukuran dari kecenderungan sebuah atom untuk menarik elektron. Elektron adalah partikel subatom yang bermuatan negatif, sedangkan karagenan adalah anionik. Sehingga semakin meningkat DD kitosan yang berinteraksi dengan karagenan dapat mempengaruhi interaksi ikatan dan sifat fisik mekanik edible film.

Kitosan yang telah diketahui nilai DD kemudian digunakan sebagai bahan campuran pada pembuatan edible film kappa dan iota karagenan. Tabel 2 menunjukkan kualitas edible film dengan variasi nilai DD kitosan yang digunakan sebagai bahan komposit.

Tabel 2. Kualitas edible film dengan variasi nilai derajat deasetilasi kitosan yang digunakan

\begin{tabular}{cccccc}
\hline Sampel & $\begin{array}{c}\text { Kadar Air } \\
(\boldsymbol{\%})\end{array}$ & $\begin{array}{c}\text { Elongasi } \\
(\boldsymbol{\%})\end{array}$ & $\begin{array}{c}\text { Kuat Tarik } \\
\left(\mathbf{N} / \mathbf{c m}^{\mathbf{2}}\right)\end{array}$ & $\begin{array}{c}\text { Ketebalan } \\
(\boldsymbol{\mu m})\end{array}$ & $\begin{array}{c}\text { Transmisi } \\
\text { Uap Air } \\
\left(\mathbf{g} / \mathbf{m}^{2} . \mathbf{j a m}\right)\end{array}$ \\
\hline DD 57\% & $17.67 \pm 0.764^{\mathrm{e}}$ & $7.27 \pm 0.394^{\mathrm{a}}$ & $41.07 \pm 0.917^{\mathrm{a}}$ & $39.86 \pm 0.385^{\mathrm{a}}$ & $0.26 \pm 0,01^{\mathrm{f}}$ \\
DD 61\% & $15.67 \pm 0.289^{\mathrm{d}}$ & $6.95 \pm 0.280^{\mathrm{b}}$ & $52.87 \pm 0.049^{\mathrm{b}}$ & $44.86 \pm 0.038^{\mathrm{b}}$ & $0.21 \pm 0,01^{\mathrm{e}}$ \\
DD 72\% & $13.50 \pm 0.500^{\mathrm{c}}$ & $7.24 \pm 0.139^{\mathrm{b}}$ & $58.85 \pm 0.506^{\mathrm{c}}$ & $50.33 \pm 0.173^{\mathrm{c}}$ & $0.14 \pm 0,01^{\mathrm{d}}$
\end{tabular}




\begin{tabular}{cccccc}
\hline DD 75\% & $12.67 \pm 0.289^{\mathrm{bc}}$ & $7.39 \pm 0.105^{\mathrm{b}}$ & $65.17 \pm 0.289^{\mathrm{d}}$ & $54.04 \pm 0.192^{\mathrm{d}}$ & $0.12 \pm 0,01^{\mathrm{c}}$ \\
DD 80\% & $11.67 \pm 1.041^{\mathrm{ab}}$ & $8.21 \pm 0.052^{\mathrm{c}}$ & $69.80 \pm 0.077^{\mathrm{e}}$ & $55.31 \pm 0.962^{\mathrm{e}}$ & $0.07 \pm 0,02^{\mathrm{b}}$ \\
DD 84\% & $10.83 \pm 0.764 \mathrm{a}$ & $8.58 \pm 0.105^{\mathrm{c}}$ & $72.76 \pm 0.273^{\mathrm{f}}$ & $58.67 \pm 0.333^{\mathrm{f}}$ & $0.05 \pm 0,01^{\mathrm{a}}$ \\
\hline
\end{tabular}

\section{Kadar Air Edible Film}

Pengaruh nilai DD kitosan terhadap kadar air edible film yang dihasilkan dapat dilihat pada Gambar 4. Kadar air edible film yang dihasilkan yaitu berkisar 10,83\% hingga $17,67 \%$.

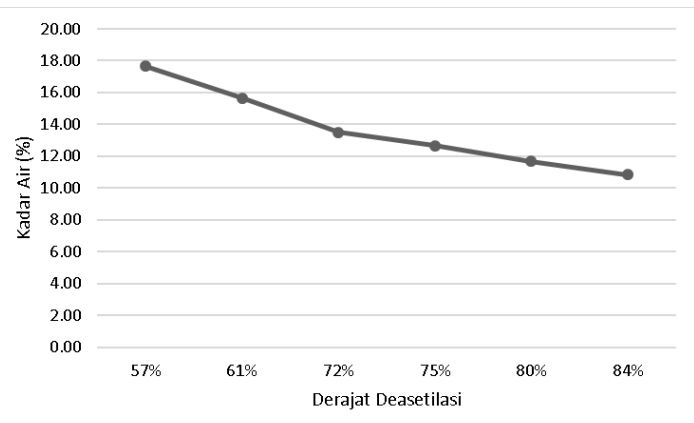

Gambar 4. Grafik pengaruh nilai derajat deasetilasi kitosan terhadap kadar air edible film

Nilai DD kitosan berpengaruh terhadap kadar air edible film $(\mathrm{p}<0,05)$. Semakin tinggi nilai DD, kadar air edible film semakin rendah. Penurunan kadar air edible film diduga dikarenakan penambahan bahan kitosan yang digunakan mampu mengikat molekul air. Kitosan dengan nilai DD yang semakin tinggi memiliki banyak gugus amin yang semakin banyak sehingga lebih bersifat polar. Kitosan mampu mengikat air melalui ikatan hidrogen yang kuat sehingga mengurangi jumlah air bebas pada edible film [16].

\section{Elongasi Edible Film}

Pengaruh nilai DD kitosan terhadap elongasi edible film yang dihasilkan dapat dilihat pada Gambar 5. Elongasi edible film yang dihasilkan berkisar antara $6,95 \%$ hingga $8,58 \%$. Nilai DD kitosan berpengaruh terhadap elongasi edible film $(\mathrm{p}<0,05)$. Nilai DD kitosan berbanding lurus dengan elongasi edible film yang dihasilkan.

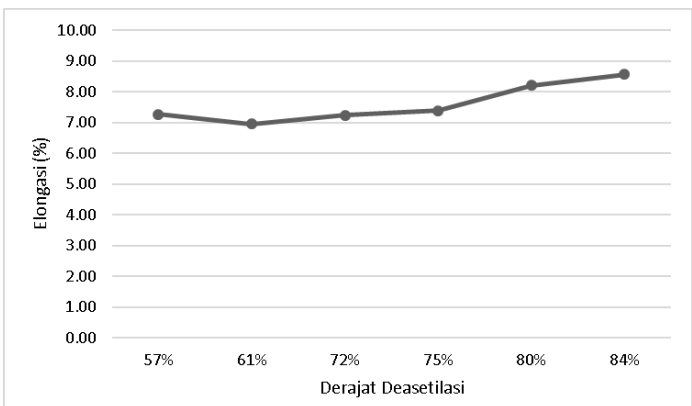

Gambar 5. Grafik pengaruh nilai derajat deasetilasi kitosan terhadap elongasi edible film Semakin tinggi nilai DD maka nilai elongasi edible film semakin naik.

\section{Kuat Tarik Edible Film}

Pengaruh nilai DD kitosan terhadap kuat tarik edible film yang dihasilkan dapat dilihat pada Gambar 6. Kuat tarik edible film yang dihasilkan berkisar antara 41,07 N/ $\mathrm{cm}^{2}$ hingga $72,76 \mathrm{~N} / \mathrm{cm}^{2}$.

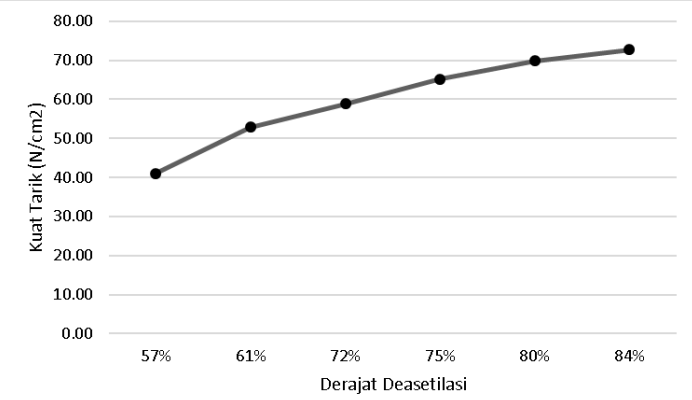

Gambar 6. Grafik pengaruh nilai derajat deasetilasi kitosan terhadap kuat tarik edible film

Nilai DD kitosan berpengaruh terhadap kuat tarik edible film $(\mathrm{p}<0,05)$. Kitosan dengan DD yang tinggi mampu mengikat dan melepas air melalui ikatan hidrogen yang lebih kuat. Kemudian akan membentuk jaringan tiga dimensi yang kompak sehingga gel yang dihasilkan lebih kuat. Liu et al [17] menyebutkan kitosan dengan DD tinggi memiliki sifat lebih reaktif terhadap karagenan melalui ikatan hydrogen dan interaksi hidrofobik. Hal ini menyebabkan kekuatan tarik pada edible film meningkat. 


\section{Kuat Tarik Edible Film}

Pengaruh nilai DD kitosan terhadap ketebalan edible film yang dihasilkan dapat dilihat pada Gambar 7. Ketebalan edible film yang dihasilkan berkisar antara 39,86 $\mu \mathrm{m}$ hingga $58,67 \mu \mathrm{m}$.

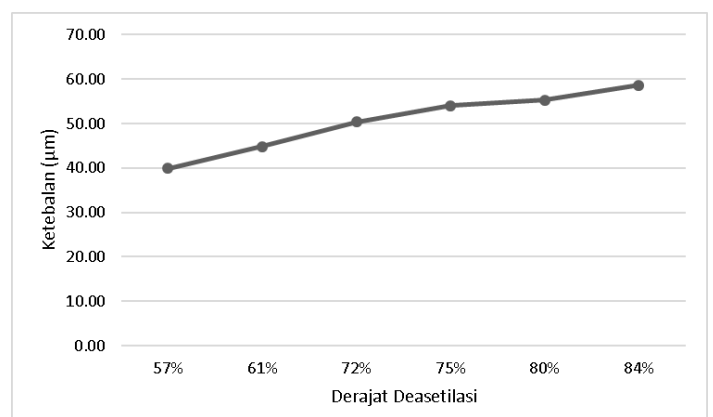

Gambar 7. Grafik pengaruh nilai derajat deasetilasi kitosan terhadap ketebalan edible film

Nilai DD kitosan berpengaruh terhadap ketebalan edible film yang dihasilkan $(p<0,05)$. Nilai DD kitosan berbanding lurus dengan ketebalan edible film. Terjadi kecenderungan peningkatan rata-rata ketebalan edible film dengan adanya penambahan kitosan.

\section{Transmisi Uap Air}

Pengaruh nilai DD kitosan terhadap nilai transmisi uap air edible film yang dihasilkan dapat dilihat pada Gambar 8. Nilai transmisi uap air dari edible film yang dihasilkan berkisar antara $0,05 \mathrm{~g} / \mathrm{m}^{2}$.jam hingga $0,26 \mathrm{~g} / \mathrm{m}^{2}$.jam.

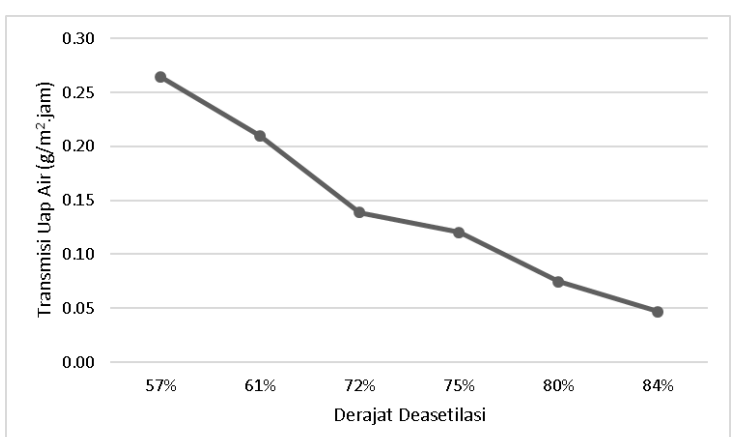

Gambar 8. Grafik pengaruh nilai derajat deasetilasi kitosan terhadap nilai transmisi uap air edible film
Nilai DD kitosan berpengaruh terhadap transmisi uap air edible film yang dihasilkan $(p<0,05)$. Semakin tinggi DD kitosan, transmisi uap air edible filmsemakin rendah. Hal ini karena kitosan merupakan polimer polar. Semakin tinggi nilai DD, jumlah ikatan hidrogen semakin besar dan penyerapan air semakin tinggi. Sehingga, penyerapan air mengganggu interaksi rantai molekular dan mampu menyerap air dari lingkungan. Krochta et al [1] menyebutkan edible film yang terbuat dari polisakarida memiliki nilai transmisi uap air yang tinggi.Akan tetapi

\section{KESIMPULAN}

Jenis dan konsentrasi alkali berpengaruh signifikan terhadap nilai derajat deasetilasi kitosan. Nilai derajat deasetilasi kitosan tertinggi didapatkan dengan perlakuan $\mathrm{NaOH}$ $65 \%$ sebesar $84,36 \%$. Nilai deasetilasi kitosan berpengaruh signifikan terhadap kualitas edible film.

\section{UCAPAN TERIMA KASIH}

Ucapan terima kasih dapat diberikan kepada Fakultas Perikanan dan Ilmu Kelautan Universitas Brawijaya.

\section{DAFTAR PUSTAKA}

[1] Krochta, J.M., Baldwin E.A, NisperosCarriedo. Edible coatings and Films to improve Food Quality. Technomic Pub.Co., Inc: Lancaster, 1994.

[2] Webber V, Carvalho S M D, Ogliar P J, Hayashi L and Barreto L M, "Optimization of the extraction of carrageenan from Kappaphycus alvarezii using response surface methodology" Cienc. Tecnol, 2012.

[3] Lascombes C, Agoda-Tandjawa G, Boulenguer P, Garnec C L, Gilles M, Mauduit, Barey $\mathrm{P}$ and langendorff $\mathrm{V}$ "Starch-carrageenan interactions in aqueous media: role of each polysaccharide chemical and 
macromolecular characteristics" J. Food Hydrocolloids., vol. 30, hal. 1-14, 2016.

[4] Zhang T, Xu X, Ji L, Li Z, Wang Y, Xue $\mathrm{Y}$ and $\mathrm{Xue} \mathrm{C}$, "Phase behaviors involved in surimi gel system: effects of phase separation on gelation of myofibrillar protein and kappacarrageenan" J. Food of International., hal. 1-25, 2017.

[5] Bosc V, Ferrari I and Michon C., "Adhesion to solid surfaces of gels of iota-carrageenan alone or in mixture with casein Colloids and Surfaces A: Physicochem", Eng. Aspects. vol. 331, hal. 2-7, 2008.

[6] Thariq, M. R. A., A. Fadli, A. Rahmat, R. Handayani, "Pengembangan Kitosan Terkini pada Berbagai Aplikasi Kehidupan: Review.", Conference: Seminar Nasional Teknik Kimia Teknologi Petro dan Oleokimia, 2016.

[7] Citrowati, A. N., W. H. Satyantini dan G. Mahasri, "Pengaruh kombinasi $\mathrm{NaOH}$ dan suhu berbeda terhadap nilai derajat deasetilasi kitosan dari cangkang kerang kampak (Atrina pectinata)", Journal of Aquaculture and Fish Health, vol. 6, no. 2, hal. 48-56, 2017.

[8] Darmajana, D. A., N. Afifah, E. Solihah, N. Indriyanti, "Pengaruh Pelapis Dapat Dimakan dari Karagenan terhadap Mutu Melon Potong dalam Penyimpanan Dingin" AGRITECH, vol. 37, no. 3, hal 280-287, 2017.

[9] Setijawati, D. "Penggunaan eucheuma sp dan chitosan sebagai bahan edible film terhadap kualitasnya", Journal of Fisheries and Marine Science, vol. 1, no. 1, hal 6-14, 2017.

[10] Wulandari, K., R. Sulistijowati, L. Mile, "Kitosan Kulit Udang Vaname Sebagai Edible Coating Pada Bakso Ikan Tuna", Jurnal Ilmiah Perikanan dan Kelautan, vol. 3, no. 3, hal. 118-121, 2015.
[11] Mohadi, R., C. Kurniawan, N. Yuliasari. "Karakterisasi kitosan dari cangkang rajungan dan tulang cumi dengan spektrofotometer FT-IR serta penentuan derajat deasetilasi dengan metode baseline", Seminar Nasional FMIPA UNSRI, 2014.

[12] AOAC Official Method of Analysis. $18^{\text {th }}$ edition, "Association of Officiating Analytical Chemists", Washington DC, 2005.

[13] Huri, D dan F. C. Nisa, "Pengaruh Konsentrasi Gliserol dan Ekstrak Ampas Kulit Apel Terhadap Karakteristik Fisik dan Kimia Edible film" Jurnal Pangan dan Agroindustri, vol. 2, no. 4, hal. 2940, 2014.

[14] Santacruz, S., Rivadeneira,C And Castro,M. "Edible film Based on Starch and Chitosan. Effect Of starch Source and Concentration, Plastiziser, Surfactan's Hydrophobic Tail and Mechanical Treatment", Journal Food Hydrocolloids, 2015.

[15] Kotz, J., Treichel, P., Townsend, J. "Chemistry and Chemical Reactivity", Cengage Learning, Feb 2008.

[16] Kusumawati, D. H. dan W. D. R. Putri. 2013. Karakteristik fisik dan kimia edible film pati jagung yang diinkorporasi dengan perasan temu hitam. Jurnal Pangan dan Agroindustri. 1(1): $90-100$

[17] Liu, Z., Ge, X., Lu, Y., Dong, S., Zhao, Y., Zeng., M. "Effect of chitosan molecular weight and degree of deacetylation on the properties of gelatine-based films." Food Hydrocolloids, vol. 26, no. 1, hal 311317, 2012. 
